<DOI: JACE14764>

<!--HELP: Attn: Typesetter; send s-proof to: John W. Halloran peterion@umich.edu

ENDHELP-->

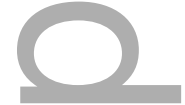

EDITORIAL

\title{
Editorial on Colloidal Processing Centennial Feature
}

The second in our series of Centennial Features is a comprehensive discussion of colloidal processing of ceramics. The term "colloid" did not appear in Volume 1 of the Journal of the American Ceramic Society, as these concepts were still very new in 1918. Of course, the colloidal properties of clay minerals were the very foundation of the ceramic field. While the details of the physical chemistry had not yet been appreciated, the practical manipulation of the rheology of slips and plastic bodies was well advanced. Many papers involved the qualities of kaolins and ball clays from particular deposits. The March 1918 issue had two such papers. Quantifying plasticity was the subject of a paper from FA Kirkpatrick and WB Orange of the National Bureau of Standards, then in Pittsburgh. Their "plasticimeter" was a clever arrangement of levers and a pendulum that measured the force to drive a cone into the plastic mass. HG Schurecht of the Bureau of Mines, then at Ohio State, presented a detailed study the effect of electrolytes on the plastic and dry properties of clays. Some of these "electrolytes" were bases and acids and materials such as tannic acid and sodium silicate, which are now recognized as strongly modifying the charge on the particles. Indeed, in a discussion after the paper W.W. Greenwood suggested that the results could be explained by the deflocculation of the clay by these electrolytes. In the Centennial Feature by Franks, Tallon, Studart, Sesso and Leo, we see a century of progress in the control of the colloidal behavior of ceramics

This is the author manuscript accepted for publication and has undergone full peer review but has not been through the copyediting, typesetting, pagination and proofreading process, which may lead to differences between this version and the Version of Record. Please cite this article as doi: 10.1111/JACE.14764

This article is protected by copyright. All rights reserved 
suspensions, inks, and pastes enables a broad range of advanced processing methods.

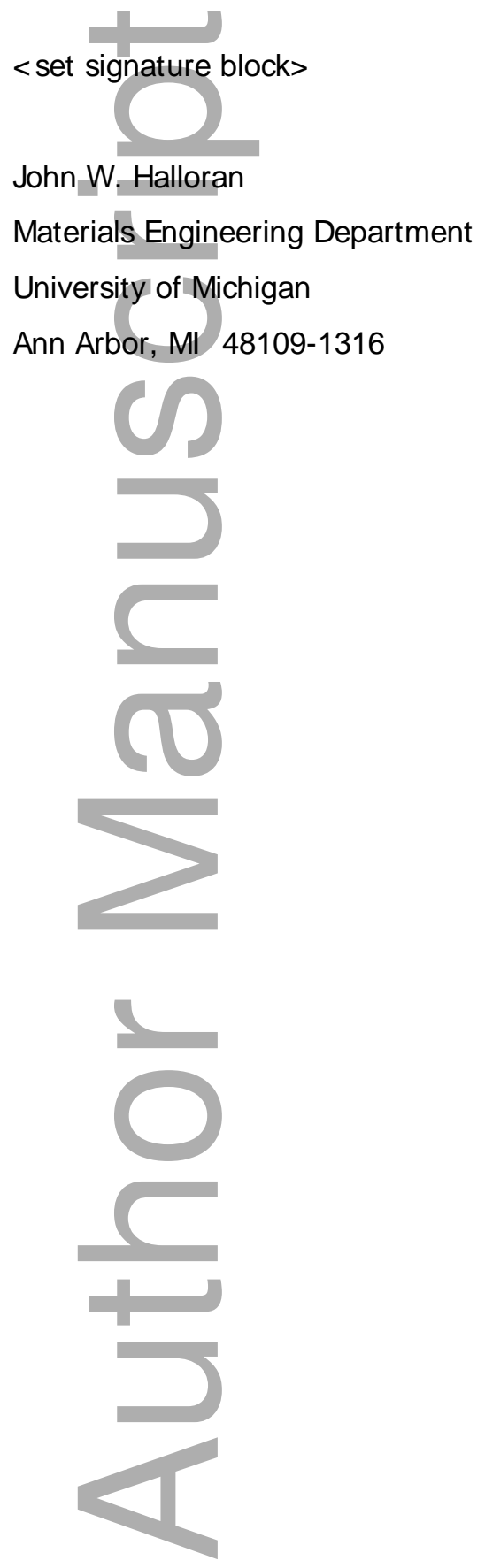

This article is protected by copyright. All rights reserved 